\title{
Review on Population Status and Conservation Activity of Indigenous Cattle Breeds of Ethiopia
}

\author{
Esubalew Shitaneh Abu \\ Ethiopian Institute of Agricultural Research, Pawe Agricultural Research Center, Livestock Research Process, \\ Pawe, Ethiopia
}

\begin{abstract}
Ethiopia has the home to at least 27 cattle breeds and an estimated 59.5 million head of cattle due to its diversified agroecology and topography and directly serves as for millions of people. Indigenous cattle breed has many important traits compared with exotic cattle breeds. Bos indicus breeds can effectively regulate their body temperature against thermal stress and are better adapted to hot weather than Bos taurus breeds. In addition, several breeds of Zebu and Zenga are able to withstand very harsh environmental conditions, and those characteristics have arisen through evolutionary adaptation. For examples, Begait cattle (Large East African Zebu) found in North-Western Ethiopia are well adapted to very dry climates and they can survive if they are able to drink only once every two days. However, despite the potential of the indigenous livestock currently, the genetic resources are becoming seriously endangered due to high genetic erosion resulting from biotic and abiotic factors. The objective of this review was to highlight threats, conservation methods and improvement activities currently done for indigenous cattle genetic resources in Ethiopia. Based on the review, among the world 1458 breeds all domestic mammalian and avian species, $17 \%$ are classified as being at risk and $58 \%$ are classified as unknown risk status. The major threats of livestock genetic resources are genetic dilution through the use of exotic germ plasma, feed shortage, illegal trafficking, inbreeding and interbreeding, and trypanosomiasis disease. This situation demands immediate action to save deteriorating genetic resources in the country. Some of endangered indigenous cattle breeds were conserved in ex-situ method at different state ranches, the Borana cattle breed as Did Tuyura Ranch, Horro cattle breed at Horro Ranch, Fogera cattle breed at Metekel Ranch and Andassa Agricultural Research Centre, and Menz sheep breed at Amed Guya Research Centre but, the results were not enough. Therefore, phenotypic and genotypic categorization of breeds will be further characterized, monitor the current population statistics, conservation of breeds under natural niche, and improvement programs will be implemented for all breeds and also improve the productivity of grazing land.
\end{abstract}

Keywords: conservation, indigenous, cattle, breed, threat, Ethiopia

DOI: $10.7176 / \mathrm{JBAH} / 11-16-01$

Publication date:August $31^{\text {st }} 2021$

\section{Introduction}

Ethiopia can be considered as a center of livestock diversity and high population because of different indigenous cattle breeds are spread out diverse ecology, communities and production systems Solomon, G (2008). It appears that the country has served as a gateway to genetic material from Asia to Africa and its diverse ecology gave rise to further diversification and thus contributed to developing the huge genotypes and host to today population (FAO, 2012). Ethiopia has the home to at least 27 cattle breeds and estimated 59.5 million heads of cattle population due to its diversified agroecology, topography and its nearness to Asia, the country is origin to African animal domestication (Nakachew Minuye et al., 2018; CSA, 2017 and EBI,2016). The existence of both Bos taurus and Bos indicus cattle in Ethiopia are evidence of cattle diversity in the country. The livestock sector contributes $12-15 \%, 12 \%$ and $33 \%$ of the total and agricultural gross domestic product (GDP) and total export earnings of country, respectively FAO (2013). Generally, cattle contribute a lot to improve the well being of the farm family through the food supply, balancing nutrition, family income, savings, insurance, ritual, transport, traction and other social purposes (Abraham Assefa and Abebe Hailu, 2018). So, these livestock genetic resources are vital to the economic development of the country.

Currently, indigenous cattle genetic resources becoming seriously endangered owing to high genetic erosion resulting from biotic and abiotic factors (Tewodros Mulualem et al.,2015). Among the world all domestic mammalian and avian species 1458 breeds, $17 \%$ of all species all breed are classified as being at risk and $58 \%$ are classified as unknown risk status (FAO,2015). In Ethiopia, indiscriminate breeding, disease, feed shortage, and agro-chemicals are some causes for threats of animal genetic diversity http://www.ibc.gov.et/biodiveristy/conservation. Feed shortage and disease burden exacerbated by climate change. Livestock health problems such as the high prevalence of Trypanosomiasis in the lowlands are among the challenges that affect livestock fertility. Sheko cattle breed is widely known to have economically important traits such as Trypanotolerance and good dairy character for use in the Trypanosomiasis infested parts of the country but, the only taurine breed in East Africa appears to be highly threatened as a result of inbreeding depression due to the small population size of cattle breeds (Workineh Ayalew et al.,2004) and Stein, J. et 
al.,2011). According to Gebeyehu Goshu et al.,2003) and Stein, J. et al.,2011) http://www.ibc.gov.et/biodiveristy/conservation study Fogera, Begait, Irob, Ogaden, Afar, and Borena cattle breeds, Sinnar donkey breed, and Afar sheep breed is facing various degrees of threat.

Therefore, vital to be characterized, conserved and properly utilize the indigenous animal genetic resources under low levels of input in the country. Conservation methods can be broadly classified into two approaches insitu and ex-situ. In-situ (on-site) conservation is the conservation of genetic resources within the natural ecosystem in which they occur, while ex-situ (off-site) conservation is the conservation of genetic resources outside the natural ecosystem in which they occur (Haileab Zegeye, 2016). Therefore, the objective of this review is to highlight threats, the status of conservation methods and improvement activities currently done to maintain and sustainable use of indigenous cattle genetic resources in the country.

\section{Cattle genetic diversity in Ethiopia}

The existence of both Bos taurus and Bos indicus cattle in Ethiopia are evidence of cattle diversity in the country. Sheko cattle breed is the only remaining descendants of indigenous African taurine cattle trypanosome tolerant in Ethiopia. West African breeds (e.g., N'Dama and Baoule), the Kuri and the Sheko breed from Ethiopia are some of breed's trypanosome tolerant in Africa. Almost (98.2\%) of the breeds are indigenous to the country (CSA, 2015). evolved over centuries, managed by smallholder farmers in remarkable diverse ecosystems (highland, dry mountain, lowlands, arid and forest) and they are often said to possess unique genetic traits. All these populations are now being intensively crossbred with Zebu cattle (Bos indicus) and their unique genetic make-up is disappearing through unbalanced genetic admixture (FAO,2007). The livestock population is primarily of local origin and not characterized as belonging to specific breeds. However, the local breeds are generally named after the area they occupy. Even amongst these identifiable types, there has been large intermixing, resulting in a dilution of livestock breed characteristics. Even though, numerous attempts made to introduce 'improved' breeds but, their success was poor in terms of achieving genetic potential. Fertility and longevity of introduced breeds so poor that frequent importation of exotic breeds necessary. Rare breeds often crossed with 'improved' breeds due to small population, dilution of breed characteristics and creation of gene pool from which it is then difficult to identify and utilize favorable local breeds genetic characteristics are also the main threats to animal genetic resources in Ethiopia (Kefyalew Alemayehu,2013).

\subsection{Description and distribution of the cattle breeds}

Ethiopian indigenous cattle breeds have unique morphological features which distinguishes them from other cattle. In addition to physical features, non-visible traits such as disease resistance, climatic stress resistance and productivity traits also differ among breeds. These characteristics are largely the result of natural and human selection. Some breeds are already known for their unique adaptive attributes (e.g., Sheko) or good economic performances (e.g., Ethiopian Boran). One of the well-known outstanding features of Ethiopian cattle is trypanosomosis resistance. Trypanosomosis is a tsetse-transmitted disease in vertebrates. In cattle the main pathogenic trypanosomes are Trypanosome Congolese and T. vivax. Temperate cattle breeds are highly susceptible to trypanosomes infection. Monitoring the population statistics for each breed and regularly reporting about the population currently at risk of extinction.

2.1.1 Abigar cattle breed

Ethiopia from early migrations and spread across south western Ethiopia into southern Sudan. Sheko cattle breeds are found around the White Nile in the Sudan and adjacent lowlands of south west of Ethiopia where they are mainly kept by the Nuer people in the Akobo area of the Gambella region (DAGRIS, 2006). They are similar to the adjacent Aliab Dinka in the Sudan, and both have retained the large body size, long horns and small humps of the true Sanga. They have straight profile head and the horns vary in length and shape but in general are very long and project outward and upward or are oval. Distinctive coat colors are light in shade, white with red and grey coat colors are also found (Albero M, Haile-Mariam S,1982). Their population size is estimated to be 548, 600 (Rege JEO, 1999) and not at risk.

2.1.2 Arsi cattle breed

Arsi cattle are mainly found in the central high- lands of Ethiopia especially in Arsi, Shewa and Bale administrative regions. Their number is estimated over 2,012,000 (Rege JEO, 1999). It is descended from the recent introductions of zebu into Africa from West Asia, and probably developed from a group of small shorthorn Abyssinian Zebu by the highland Oromo people (DAGRIS,2006). They are small, short and compact. Red, with a black muzzle, is the predominant color although many animals are black, light grey or white with black spots. It is classified in to zebu cattle type (Albero M, Haile-Mariam S,1982) and (Tesfaye C. et al.,1994). 2.1.3 Begait Cattle breed

Begait cattle breed, alternatively called Barka, is believed to be originated from Sudan and low lands of Eritrea Zerabruk M, et al.,2007b). They are currently, found in Humera area of Ethiopia. Begait cattle is phenotypically relatively large in size with a well-developed udder, small and stumpy horns in both male and females, long teats, 
a higher milk yielder and aggressive nature (Ibid). The common coat colors are grey, brown, and black and white. In terms of susceptibility, they are very vulnerable to food shortage.

2.1.4 Boran cattle Breed

According to Nigatu A. et al. (002) report Boran cattle are being raised by both the Boran and Somali ethnic groups in Ethiopia. They were further distributed by the nomads of southern Ethiopia and Somalia who migrated to Kenya and in the late 1920s where by European ranchers in Kenya purchased these cattle and developed the improved Boran or Kenya Boran through selective breeding. It was then introduced to Zambia in 1947 and to South Africa in the 1960s (BCBSSA, 2005). With regard to the phenotypic characteristics of the breed Gillooly JF, et al., 2001) described that a typical Boran cattle have white coat color and large dewlap and hump. But mostly they have light grey or fawn with black or dark brown shading on the neck, head, shoulders and hindquarter and shorter, more pendulous sheath, well developed hump, well developed udder, long legs, wide ear and large dewlap and erect horn orientation with dominantly thick base (Getachew G and Nigatu A, 2001). Nigatu A. et al.,2002) and Getinet M (2005). However, based on the survey report of Nigatu A. et al., 2002) it was revealed that the Ethiopian Boran cattle known by the community 50 years ago were not identical with the current Ethiopian Boran types, especially in terms of their body size and coat color. These phenotypic characteristics are a result of adaptation mechanisms of the breed to the harsh environments. For instance, white color is helpful in thermo-regulation ability; long legs to trek long (60 km per day) and wide ear and large dewlap help to increase the surface area for metabolic heat dissipation. Those of Somali Boran cattle have white with black patches coat color Nigatu A. et al., 2002).

2.1.5 Fogera Cattle Breed

Fogera cattle breed are considered as a definite breed which inhabits the Fogera plains around Lake Tana, Ethiopia having its own defined phenotypic and genetic characteristics. Regarding its origin there are two schools of thoughts as stated by different scholars. According to the hypothesis of (Mpofu N, 2002), the nomads from the south moved northwards and settled with their cattle in the areas of west and south of Lake Tana where the cattle became known as Tana land Boran. According to (Zewdu W, 2004) and Zerabruk M, et al., 2007b) it is believed that it is a Zebu x Sanga (called Zenga) breed. Despite the low bootstrap estimates that indicate the sampling bias, the protein polymorphism as well as nuclear DNA reports discovered the close relationships between Fogera cattle (the breed currently found around Lake Tana) with Boran or Ogaden cattle breeds (Dadi H, et al, 2008). The coat color of Fogera cattle breeds varies, black and white or black and grey coat (Zerabruk M, et al.,2007b). Most of their characteristics (small horns, very large dew-lap, pendulous naval flap and perpetual sheath, docile) indicate the characteristic of zebu cattle (Zewdu W, 2004) and Nigatu A. et al.,2002). Only the hump, which in most of the cases is rather small and cervical or cervico-thoracic in position (Rege JEO, 1999) represents the Sanga genetic influence. These cattle, therefore, have been classified by breeders as intermediate zebu-Sanga type. This breed was developed through interbreeding of various breeds.

2.1.6 Horro cattle breed

Abyssinian Highland Zebu and Nilotic Sanga, particularly the Abigar. The breeds that emerged from these crosses have been classified in a separate group of "Zenga" cattle (DAGRIS, 2006). According to (Albero M, Haile-Mariam S,1982) and Tesfaye C.et al 1994) also grouped the Horro in to Sanga-Zebu (Zenga) type. They are very good-looking animals being uniform in color and body conformation. They are of medium to large size, with small and finely shaped head, a straight profile and medium to large horns. The hump is small to medium in size. The Horro cattle have a uniform brown color which is slightly lighter around the muzzle and on the flank. Although the total number of populations is not yet recorded, (DAGRIS, 2006). reported that the breed is not at risk of genetic erosion.

2.1.7 Sheko cattle Breed

Sheko cattle is found only in the remote corner of southwestern Ethiopia specifically at the humid Sheko and Bench districts owned by small holder farmers who breed them for millennia of years for their natural resistance to disease, particularly tsetse-transmitted trypanosomiasis (ILRI,2007). This breed represents the last remnants of Africa ${ }^{e e}$ s original Bos-taurus (humpless shorthorn) cattle which were probably the first to be domesticated in eastern Africa (ILRI,2007). The phylogenetic, genetic distance based; analysis of the breed indicated that Sheko cattle are distantly related to Sanga cattle breeds of Ethiopia (Dadi H.et al.,2008). They are smaller in body size, with narrower belly and hindquarters, and shorter or no horns which made them much easier to manage (Takele T. et al.,2009). Sheko cattle have better feed conversion efficiency, longevity and fertility good mothering ability compared to other cattle breeds in adjacent areas. However, these days some of the Sheko cattle manifest small humps that they inherited from zebu introgression (Tatek W and Abegaz B, 2013). On the other hand, their occasional aggressive temperament and voracious feeding habits, particularly during the dry season, were mentioned as undesirable traits which trigger its keepers to intentionally reinstate with smaller breeds of lower feed intake (Takele T. et al.,2009). 


\subsection{Threats to livestock genetic resources}

According to the FAO (2007) report from 7600 breeds about (20\%) worldwide, belonging to 18 mammalian species and 16 avian species are at risk and 62 breeds became extinct within the first 6 years of this century. The African continent is the home to 145 cattle breeds/strains and $22 \%$ of the original breeds have become extinct in the last 100 years and $27 \%$ of the remainder is at varying degrees of risk Rege J.E.O. et al.,2002). Today $70 \%$ of the livestock breeds existed in developing countries where the risk of loss is highest. The major threats of indigenous cattle genetic resource turn down are feed shortage as a result of degradation of rangelands/grazing areas, overgrazing and overstocking; sporadic invasion of rangelands by weeds and shrubs, expansion of crop cultivation, illegal trafficking, poorly designed and managed introduction of exotic genetic materials, weak development interventions, inbreeding and interbreeding and Trypanosomiasis. Various ongoing development interventions like Artificial insemination and introduction of genotypes into new environments that are aggravates the threat of the breeds should be avoided by revising and designing sound approaches for cattle conservation and improvement programs (Kefyalew Alemayehu, Addis Getu, 2015) and Nigatu A. et al.,2004). Without breeding strategic scheme extensive importation of exotic germ plasma is one of the major causes for genetic dilution or eradication of indigenous cattle breeds in the country. An example is the global impact of the North American Holstein-/Friesian cattle on other dairy breeds, in some case entire breeds have effectively been replaced by this breed. The application of artificial insemination in indigenous cattle using semen from exotic cattle breeds are resulting in the unpredicted substitution of indigenous genes by exotic genes (ESAP,2004) and Pilling, D, 2010). The application of these technologies for germplasm propagation and dissemination may contribute to the erosion of diversity.

Ethiopian indigenous breed like Abergelle, Anuak, Adwa, Afar, Arado, Begaria, Gofa, Gurghe, Gojjam Highland Zebu, Hammer, Harar, Jemjem, Kereyu, Jijiga, Medense, Raya, and Smada cattle was conventionally conserved by farmers. In line with this Borana, Bageit, Fogera, Horro, Irob, Ogaden Zebu, Sheko cattle were insitu conservation and selection with ranch and ex-situ conservation with cryopreservation activity implemented but Ambo cattle breed was improved by crossing with exotics. In general, the risk factor of most indigenous cattle breeds is not further studied shown in Table.1. The population of Fogera breed had declined due to the dominancy of small-sized zebu breeds through crossbreeding and flock change due to lack of animal feed (Assemu Tesfa et al.,2017). The shift from livestock dominant mixed crop-livestock production system to crop dominant mixed crop-livestock system has also affected the indigenous Fogera and Begait cattle breeds. In this regard, the expansion of dominantly rice, sesame, and other crop farming at the expense of productive communal lands is interfering with the production and productivity potential of the breeds (Mekuriaw, G. and Kebede, A, 2015).

The population of pure Fogera cattle is not viable and the population growth is at decreasing trends as a result of feed shortage, cross-breeding with other indigenous breeds, disease, and parasites (Kefyalew Alemayehu et al.,2015). The mean time required for the counts to decline from the existing population size to 300 individual animal extinction thresholds is 162.7 years unless faced by stochastic and deterministic disturbances (Kefyalew Alemayehu et al., 2015). According to (Kefyalew Alemayehu et al., 2015) study 86, 87 $\& 78 \%$ of sample respondents from Bahir Dar Zuria, Fogera and Dera district reported that the populations of Fogera breed decrease from time to time.

In other words, Sheko is now considered endangered by gradual interbreeding with the local zebu (DAGRIS, 2004). [41]. With this respect, the molecular genetic evidence also showed that about $90 \%$ of the sampled Sheko bulls have had their specific taurine allele replaced by indicine allele confirming an alarming introgression of Zebu genes Hanotte $\mathrm{O}$ et al.,2000). This, calls for an immediate conservation and improvement program to reverse or at least halt further decline of the breed. On the other hand, pastoralists identified scarcity of pasture in Borana rangeland due to the increasing recurrence of droughts as the main cause shrinkage of the grazing land (Sabine H et al.,2004). The study of (Nakachew Minuye et al., 2018) has shown that the gradual decreasing trend of the Abigar cattle population in the region due to frequent drought, prevalence of disease, and feed shortage.

\subsection{Livestock genetic resources conservation approach}

Conservation of livestock diversity has been defined as the total sum of all operations involved in the management of animal genetic resources so that the pool of genetic diversity is maintained (Hammond, K, 1993) and (ILRI, 2006). It encompasses the management of human activities in such a way that animal genetic resources are best utilized and developed to meet immediate and long-term human needs for future generations. Loss of genetic diversity will likely decrease the ability of animals breed to respond to environmental change and will result in a loss of genetic information potentially useful for breeding improvement (Hunter, M.L.J, 1996). Most attention in the conservation of animal diversity has been intended for rare breeds. According to FAO (1995) strategies identified for effective management of domestic animal diversity at the global level for each species are: Identifying and listing all breeds and describing and characterizing breeds to understand their unique 
qualities and potential contributions to the future. Sorting adequate samples at the same time as many breeds as possible, generally in the form of frozen semen, ova, and embryos, to enable the future regeneration of lost populations of animals. There are two major approaches of conservation for livestock genetic resources are available.

\subsubsection{In-Situ Conservation}

In-situ conservation, also called 'on-farm conservation', can be defined as the continuous husbandry of populations by farmers in the agro-ecosystems where those populations have evolved (Hammond, K, 1994). Thus, in-situ conservation encompasses entire ecosystems, including immediately useful species of animals that form part of the system. The disadvantages are that selection and genetic drift may result in unfavorable genetic changes if the population is small. There is a risk of increasing inbreeding and hence homozygosity, which is associated with reduced fitness. The animals are at risk from disease and other natural disasters. Also, they are likely to be less productive and so more coasty to maintain. In Ethiopia, institutions involved in-situ conservation of biodiversity includes the IBC, the Ethiopian Institute of Agricultural Research, Regional Agricultural departments, Higher Learning Institutions, etc. However, the impact of their work on the conservation of biological resources in practical terms is very limited (IBC, 2005). So, identifying the status of the livestock genetic resources and designing conservation strategies based on the priorities is crucial.

Table 1. Some of Indigenous Cattle Breed, Location, Population Status, Improvement and Conservation Activity

\begin{tabular}{|c|c|c|c|}
\hline Breed Type & Location Breed Found & Current Population\& Status & Improvement Action \\
\hline Abergele cattle & $\begin{array}{lll}\begin{array}{l}\text { Amhara } \\
\text { region }\end{array} & \& & \text { Tigray } \\
\end{array}$ & Unknown & Normally practiced by farmers \\
\hline $\begin{array}{l}\text { Anuak/Abigar } \\
\text { cattle }\end{array}$ & Gambella region & $\begin{array}{l}\text { Unknown but limited due to } \\
\text { trypanosomes \& drought }\end{array}$ & Normally practiced by farmers \\
\hline Arsi cattle breed & $\begin{array}{l}\text { Central highland part of } \\
\text { Ethiopia }\end{array}$ & Diluted with the exotic breed & Unknown \\
\hline Bagiat cattle & $\begin{array}{l}\text { Northwest part of } \\
\text { Ethiopia }\end{array}$ & $\begin{array}{l}\text { Decrease due to feed } \\
\text { shortage }\end{array}$ & $\begin{array}{l}\text { Improvement in ranch \& ex- } \\
\text { situ conservation }\end{array}$ \\
\hline Begaria cattle & $\begin{array}{l}\text { Benishangul } \\
\text { Region }\end{array}$ & Unknown & $\begin{array}{l}\text { Community-based } \\
\text { conservation }\end{array}$ \\
\hline Bale cattle & The high plateau of Bale & Unknown & Normally practiced by farmers \\
\hline Boran cattle & $\begin{array}{l}\text { Southern rangeland of } \\
\text { Ethiopia }\end{array}$ & $\begin{array}{l}\text { High risk of destocking and } \\
\text { critically endangered }\end{array}$ & $\begin{array}{l}\text { In-situ \& ex-situ conservation } \\
\text { implemented }\end{array}$ \\
\hline Fogera cattle & $\begin{array}{l}\text { Around lake } \\
\text { Amhara Region }\end{array}$ & $\begin{array}{l}\text { Dilution risk with small } \\
\text { indigenous breeds }\end{array}$ & $\begin{array}{l}\text { Selection in ranch, in-situ \& } \\
\text { ex-situ } \\
\text { practiced }\end{array}$ \\
\hline $\begin{array}{l}\text { Gojjam high land } \\
\text { zebu cattle }\end{array}$ & $\begin{array}{l}\text { Distributed in Awi, East } \\
\text { \& West Gojjam area }\end{array}$ & $\begin{array}{l}\text { Uncontrolled breeding with } \\
\text { other indigenous breeds }\end{array}$ & Normally practiced by farmers \\
\hline Horro cattle breed & $\begin{array}{l}\text { Eastern welega, Shewa, } \\
\text { Illibabur area }\end{array}$ & Unknown & $\begin{array}{l}\text { Ranches \& community } \\
\text { breeding activity practiced }\end{array}$ \\
\hline Irob cattle breed & Found in Tigray region & $\begin{array}{l}\text { Unknown \& threatened due } \\
\text { to lack of awareness }\end{array}$ & Ex-situ conservation applied \\
\hline $\begin{array}{l}\text { RayaAzabo cattle } \\
\text { breed }\end{array}$ & $\begin{array}{l}\text { Found in Tigray \& } \\
\text { Wollo area }\end{array}$ & $\begin{array}{l}\text { Unknown but, dilution with } \\
\text { other local breeds }\end{array}$ & Normally practiced by farmers \\
\hline Sheko cattle breed & $\begin{array}{l}\text { The southern part of the } \\
\text { country }\end{array}$ & $\begin{array}{l}\text { Population } 2400 \& \text { critically } \\
\text { endangered due to dilution, }\end{array}$ & $\begin{array}{l}\text { In-situ \& ex-situ methods of } \\
\text { conservation undertaken }\end{array}$ \\
\hline
\end{tabular}

Source: (Nakachew Minuye et al., 2018) and EBI (2016)

2.3.2 Ex-Situ Conservation

Ex-situ approaches to conservation include maintaining breeds in the farm, creating a conservation herd (gene pool) and cryo-preservation (of semen and embryos) and keeping of live animals in designated localities, e.g., government farms or ranches. In marked contrast to the situation in plants, cryo-preservation is technically feasible for very few livestock species. In the context of conservation of domestic animal diversity in Ethiopia, there are three ex-situ conservation methods (Tewodros Mulualem et al., 2015). Maintaining breeds in the farm it involves the breeding animal's sample of a breed outside its normal production habitat. Many of the pros and cons of this approach are similar to the in-situ conservation method. However, there is potentially more control over the management of the population.

2.3.3 Creating a Conservation Herd (Gene Pool)

This involves crossing several rare breeds together, then breeding them to maintain genetic variability. It is an effective way of conserving genetic variation for two or three breeds. Maintenance of genetic diversity is almost better served by pooling five breeds in a conservation herd (Notter, D.R. et al.,1994). However, there is a greater 
risk of losing useful genes when more populations are combined. The disadvantage of this approach is that, although useful genes may be conserved, the identity of individual breeds is lost.

2.3.4 Cryo-Preservation

This involves frozen storage of rare breeds in the form of living semen, ova, embryos or tissues, which can be used to regenerate animals. Cryopreservation of semen and embryos is a powerful tool for the preservation of genetic diversity. In the situation of a critical threat with a high probability that a breed will become extinct, preservation of genetic material of individual animals in the form of germ cells and embryos is necessary to ensure that an adequate genetic pool is retained for future improvement programs. Breeding technologies as artificial insemination and embryo transfer may provide support for this approach. The use of frozen semen in the conservation program is particularly feasible where traditional use of AI is already strong in Ethiopia. The collection of semen of endangered local breeds should take place as part of the AI program. According to Habtamu Lemma (2012) study concluded that developing and using indigenous breeds in government ranches and research centers and establishing Gene Bank for Cryo-preservation of adapted animal germplasm (gametes, embryos.) from endangered breeds (e.g., Sheko and Borena) to backup maintenance of live animals. In this regard, the experiences of countries- Benin, Brazil, China, India, and Kenya (Gandini et al.,2004) can be taken into consideration.

Conservation aims at farm animal genetic resources ranging from avoiding extinction, maintaining genetic diversity and/or the cultural, ecological or socio-economic values of breeds, to provide the right conditions for their evolution within an evolving production system (Gandini et al., 2004) and Solomon, G et al.,2007). Although much information is lacking, conservation of farm animal genetic resources (AnGR) in the Ethiopian perspective should be viewed from the rational utilization and protection of existing genotypes from genetic erosion (IBC, 2004). According to (Berhane Hagos, 2017). study indicated that comprehensive characterization, conservation, and improvement programs have to be designed to utilize the genetic resource sustainably. Moreover, the future direction for the development of this sector should better be geared towards the selection and improvement of local breeds, while cross-breeding and replacement can be used in the urban and peri-urban areas applying the controlled cross-breeding strategy (IBC, 2004) and (Berhane Hagos, 2017).

In Ethiopia, some activities carry out to maintain pure stocks of three cattle breeds and one sheep breed, but conservation activities of farm AnGR have not so far been practiced in the country. Some of the ranches was Borana cattle bred as Did Tuyura and Abernossa Ranch, Horro cattle breed at Horro Ranch, Fogera cattle breed at Metekel ranch and Andassa Agricultural Research Centre and Menz sheep breed at Amed Guya Research Centre, Wolaita cattle ranch and Jigjiga ogaden cattle ranch are the only conservation attempts made in Ethiopia (IBC, 2004). The newly established ranches are Begait cattle ranch at Humera and Horro cattle ranch at Bako (Abraham Assefa and Abebe Hailu, 2018).

\section{Conclusion and Recommendation}

From the above review, Ethiopia can be considered as a center of livestock diversity. Indigenous cattle breeds like Abigar, Arsi, Begait, Begaria, Boran, Fogera, Gojjam highland zebu, Irob, Sheko, etc.... are threatened gradually. Some of activities were performed to conserve critically endangered indigenous cattle breeds in exsitu conservation method at different ranches and research centers. Borana cattle breed at Did Tuyura Ranch, Horro cattle breed at Horro Ranch, Fogera cattle breed at Metekel Ranch and Andassa Agricultural Research Centre, and Menz sheep at Amed Guya Research Centre are the only conservation attempts made in Ethiopia and other cattle breeds conventionally conserved by farmers. Generally, I will recommend from review point of view, on-farm and station phenotypic and genotypic characterization activities so far will be carried out those breeds not further characterized and monitored their population statistics. Improving the productivity of grazing land should be done to maintain indigenous cattle breeds in their natural habitat. The government should be by allocating enough budgets to establish new and to maintain existing ranches and research centers to conserve those endangered indigenous cattle breeds.

\section{Reference}

Abraham Assefa and Abebe Hailu (2018). Ethiopian Indigenous Cattle breed's Diversity, Distribution, Purpose of keeping and their potential threats. J. Bio.Innov,7 (5): 770 -789, Issn2277-8330. [9] FAO (2015). FAO statistical pocketbook world food and Agriculture. Food and Agriculture Organization of the United Nation, Rome, 2015.

Albero M, Haile-Mariam S (1982). The indigenous cattle of Ethiopia. Part I. World Anim. Rev. 41: 2-10.

Assemu Tesfa, Dilip Kumar, Solomon Abegaz and Getinet Mekuriaw (2017). Conservation and Improvement Strategy for Fogera Cattle: A Lesson for Ethiopia Ingenious Cattle Breed Resource. Hindawi Advances in Agriculture. https://doi.org/10.1155/2017/2149452

BCBSSA (2005). Boran Cattle Breeders" Society of South Africa. The Boran breed manual in South Africa. Berhane Hagos (2017). Ethiopian Cattle Genetic Resource and Unique Characteristics under a Rapidly Changing 
Production Environment-A Review. International Journal of Science and Research (IJSR). ISSN (Online) 6 (12): 2319-7064, www.ijsr.net

CSA (2015). Report on Livestock and Livestock Characteristics (private peasant holdings). Statistical bulletin, $578(2)$.

CSA (2017). Report on Livestock and Livestock Characteristics (Private Peasant Holdings) Addis Ababa April 2017, Statistical Bulletin, 585 (2).

Dadi H, Tibbo M, Takahashi Y, Nomura K, Hanada H and Amano T (2008). Microsatellite analysis reveals high genetic diversity but low genetic structure in Ethiopian indigenous cattle populations. International Society for Animal Genetics, Animal Genetics, 39: 425-431

DAGRIS (2004). Domestic Animal Genetic Resources Information System (DAGRIS). ed., J.E.O. Rege, W. Ayalew and Getahun). International Livestock Research Institute, Addis Ababa, Ethiopia.

DAGRIS (2006). Domestic Animal Genetic Resources Information System, Rege JEO, Ayalew W, Getahun E, Hanotte O, Dessie $\mathrm{T}$ (eds). International Livestock Research Institute, Addis Ababa, Ethiopia. http://dagris.ilri.cgiar.org. Addis Ababa, Ethiopia.

EBI (2016). Institute of Biodiversity Conservation. The state of Ethiopia's Farm animal genetic resources: country report. A contribution to the $1^{\text {st }}$ report on the state of the world's animal genetic resources. Addis Ababa, Ethiopia.

ESAP (Ethiopian Society of Animal Production) (2004). Farm Animal Biodiversity in Ethiopia: Status and Prospects. Proceedings of the 11th Annual Conference of the Ethiopian Society of Animal Production (ESAP) held in Addis Ababa.

FAO (1995). World watch list for domestic animal diversity $2^{\text {nd }}$ ed., Food and Agricultural organization of the United Nations, Rome, Italy,7: 69.

FAO (2007). The state of the World's Animal Genetic Resources for Food and Agriculture.FAO.Rome, Italy. http://www.fao.org/docrep/010/a1250e/a1250e00.htm

FAO (2012). FAOSTAT. Statistical database of the Food and Agriculture Organization of the United Nations, Rome., Italy.

FAO (2013). FAOSTAT Statistical database of the Food and Agriculture Organization of the United Nations, Rome., Italy.

FAO (2015). FAO statistical pocketbook world food and Agriculture. Food and Agriculture Organization of the United Nation, Rome, 2015.

FDRE (Federal Democratic Republic of Ethiopia) (2005). Institute of Biodiversity Conservation, National Biodiversity Strategy and Action Plan. Addis Ababa, Ethiopia.

Gandini, G.C., Ollivier, L, Danell, B, Groeneveld, E., Martyniuk, E., Woolliams, J.A (2004). Criteria to assess the degree of endangerment of livestock breeds in Europe, Livest. Prod. Sci, 91: 173-182.

Gebeyehu Goshu, Azage Tegegn, Tezera Mulugeta, and Aklilu Agdie (2003). Preliminary Report on the distribution of Fogera cattle around Lake Tana, Ethiopia. Proceedings of $11^{\text {th }}$ annual conference of the Ethiopian Society Animal production. August28-30, Addis Ababa, Ethiopia, Pp. 203-208.

Getachew G and Nigatu A (2001). A snap Survey on Pastoralists perception on genetic dissipation of Boran Cattle. Unpublished Report.

Getinet M (2005). Ex-situ morphological and phenotypic characterization of Ogaden cattle at Alemaya University. MSc Thesis, Alemaya University, Ethiopia.

Gillooly JF, Brown JH, West GB, Savage VM and Charnov EL (2001). Effects of Size and Temperature on Metabolic Rate. Science, 21 Sept. 2001: 293.

Habtamu Lemma (2012). Domestic Animal Biodiversity in Ethiopia and its Threats and Opportunities with Emphasis to Changing Climate: An Overview Advances in Life Science and Technology ISSN 2224-7181 Vol.6.www.iiste.org.

Haileab Zegeye (2016). In situ and ex situ conservation: Complementary approaches for maintaining biodiversity. IJRES41-12ISSN2059-1977.

Hammond, K (1993). Why conserve animal gene resources? Diversity, 9 (3): 30-35.

Hammond, K (1994). Why conserve animal gene resources? Diversity, 9 (3): 30-35.

Hanotte O, Tawah CL, Bradley DG, Okomo M, Verjee Y, Ochieng J (2000). Geographic distribution and frequency of a taurine Bos taurine and an indicine Bos indicus Y specific allele amongst sub-Saharan African cattle breeds. Mol Ecol, 9: 387-396.

Hunter, M.L.J (1996). Fundamentals of conservation biology. Blackwell Science, Inc. Cambridge, Massachuse s, USA, 482pp.

IBC (2004) Institute of Biodiversity Conservation. The state of Ethiopia's Farm Animal Genetic Resources: A contribution to the first report on the state of the world's animal genetic resources. May 2004, Addis Ababa, Ethiopia.

ILRI (International Livestock Research Institute) (2006). Animal Genetics Training Resource, version 2. Ojango, 
J.M., Malmfors, B. and Okeyo, A.M. (Eds). Nairobi, Kenya, and Swedish University of Agricultural Sciences, Uppsala, Sweden.

ILRI (International Livestock Research Institute) (2007). Science in Africa: Africa's First On-line Science magazine, http://www.scienceinafrica.co.za/2007/october/cows.htm

Kefyalew Alemayehu (2013). Threats, attempts and opportunities of conserving indigenous animal genetic resources in Ethiopia. African Journal of Agricultural Research, 8 (23): 2806-2813. DOI:10.5897/AJAR12.1720. http://www.academicjournals.org/AJAR

Kefyalew Alemayehu, Addis Getu (2015) The Role of Population Genetics for Ethiopian Farm Animal Genetic Resources Conservation, IJSRST, 1 (3) Print ISSN: 2395-6011 Online ISSN: 2395-602X.

Kefyalew Alemayehu, Damitie Kebede, Endalkachew Girma (2015). Survival and population viability of Fogera cattle (Bos indicus, Zenga Type) in North West Amhara, Ethiopia. Global Journal of Animal Breeding and Genetics, 3 (6):181-187. ISSN: 2408-5502.

Mekuriaw, G. and Kebede, A (2015). A review on indigenous cattle genetic resources in Ethiopia: adaptation, status, and survival. Online J. Anim. Feed Res., 5 (5): 125-137.

Mpofu N (2002). The multiplication of Africaes indigenous cattle breed internationally: The story of the Tuli and Boran breeds. AGTR Case Study. Nairobi, Kenya: ILRI. https://cgspace.cgiar.org/handle/10568/3600.

Nakachew Minuye, Girma Abebe and Tadelle Dessie (2018). On-farm description and status of Nuer (Abigar) cattle breed in Gambella Regional State, Ethiopia. International Journal of Biodiversity and Conservation, 10 (6): 292-302, DOI: 10.5897/IJBC2017.1168

Nigatu A, Getachew G and Workneh A (2002). Genetic dilution of the Ethiopian Boran cattle. pp 377-381. In: Proceeding of 10th National Conference. Ethiopian Society Animal Production (ESAP). Aug 21-23, 2002.

Nigatu A, Getachew G, Drucker AG (2004). Reasons for the loss of animal genetic resources (AnGR) and the importance of indigenous knowledge in AnGR Management. Proceedings of the $11^{\text {th }}$ Annual Conference of the Ethiopian Society of Animal Production (ESAP), August 28-30, 2003, Addis Ababa, Ethiopia. pp. 3145.

Notter, D.R.; Mariante, A.D.S., and Sheng, Z (1994). The modern approach to active conservation of domestic animal diversity. In: Proceeding of the 5th World Congress of Gene Applied to Livestock Production. 7-12 August, Guelph, Canada, 21: 509-516

Pilling, D (2010). Threats to animal genetic resources for food and agriculture- approaches to recording, description, classification, and analysis. Animal Genetic Resources, 47:11-22.

Rege J.E.O.; Muigai, A.W.T. and Hano e, O (2002). Assessment of genetic diversity in African small ruminants: present status and prospects. In: 53rd Annual Meeting of the European association of animal production, Cairo, Egypt, 1-7pp.

Rege JEO (1999). The state of African cattle genetic resources. I. Classification framework and identification of threatened and extinct breeds. FAO/UNEP Anim. Gen. Res. Info. Bull. 25: 1-25.

Sabine H, Barbara R, Jörg S and Workneh A (2004). Disturbed Traditional Resource Management affects the Preservation of the Boran Cattle in their Original Habitat. Eth. J. Anim. Prod, 4(1): 33-44.

Solomon, G (2008). Sheep resources of Ethiopia genetic diversity and breeding strategy. Ph.D. Dissertation at Wageningen University, the Netherlands, 9-12pp.

Solomon, G.; Van Arendonk, J.A.M.; Komen, H.; Windig, J.J. and Hano e, O (2007). Population structure, genetic variation, and morphological diversity in indigenous sheep of Ethiopia, Anim. Genet., 38: 621-628.

Stein, J., Ayalew, W., Rege, E., Mulatu, W., Lemecha, H., Tadesse, Y., Tekle, T., and Philipsson, J (2011). Trypanosomiasis and Phenotypic features of four indigenous cattle breeds in an Ethiopian field study. Veterinary Parasitological. DOI: 10.1016/j.vetpar.2010.12.025.

Takele T, Workneh A and Hegde BP (2009). Status of Ethiopian indigenous Sheko cattle breed and the need for participatory breed management plan. Eth. J. Anim. Prod. 9(1) - 2009: 1-12.

Tatek W and Abegaz B (2013). Current Status and Future Prospects of the Endangered Sheko Breed of Cattle (African Bos Taurus) in Ethiopia: A Review Paper.

Tesfaye C, Emiru Z, Mulugeta S, Bruk Y (1994). Livestock breed types and improvement programs in Ethiopia. National Artificial Insemination Center, Addis Ababa, Ethiopia. pp. 1-6

Tewodros Mulualem, Meseret Molla and Merkebu Getachew (2015). Assessment of livestock genetic resource diversity in Ethiopia: An implication for conservation Journal of Genetic and Environmental Resources Conservation, 3 (2):150-163. www.jgerc.com.

Workineh Ayalew, Ephrem Getachew, Markos Tibbo, Yetnayet Mamo and J.E.O. Rege (2004). The current state of knowledge on the characterization of Farm Animal Genetic Resources in Ethiopia. Proceedings of $11^{\text {th }}$ annual conference of the Ethiopian Society of Animal production. Addis Ababa, August 28-30, 2003.ESAP, Addis Ababa Ethiopia. Pp. 1-22.

Zerabruk M, Vangen O and Haile M (2007b). The status of cattle genetic resources in North Ethiopia: On-farm characterization of six major cattle breeds. Animal Genetic Resources Information, No. 40, 2007. 
Zewdu W (2004). Indigenous cattle genetic resources, their husbandry practices and breeding objectives in North-western Ethiopia. An MSc Thesis Submitted to School of Graduate Studies, Alemaya University. [24] BCBSSA (2005). Boran Cattle Breeders" Society of South Africa. The Boran breed manual in South Africa. 